Awards of 5,000 dollars and Awards of Merit of 25,000 dollars are bestowed on those who "have made contributions to the conquest of disease and the relief of human suffering". The following are the most recently announced:

Award of Merit to Dr. Murray L. Barr, head of the Department of Anatomy, University of Western Ontario, for his discovery of the fundamental difference between male and female cells, thus contributing to greater knowledge of factors governing heredity.

Annual Awards to: Dr. Jacques Genest, director of clinical research, Hotel Dieu Hospital, Montreal, for his work on high blood-pressure; Prof. C. Walton Lillehei, professor of surgery, University of Minnesota, Minneapolis, for development of sevoral pioneering techniques in open heart surgery; Dr. Irvine H. Page, director of research, Cleveland Clinic Foundation, Cleveland, Ohio, for discoveries linking the kidney to high blood-pressure; Prof. E. G. L. Bywaters, professor of rheumatology, University of London, for his work on the clinical features of rheumatoid arthritis which have delineated the special features of the course of the disease; Dr. Pierre Grabar, director of the French National Cancer Research Institute, Paris, for contributions to the knowledge of the identity of proteins which have aided research in immunology and leukæmia.

\section{NATO Advanced Study Institutes : Grants}

THE North Atlantic Treaty Organization is offering grants towards the organization of Advanced Study Institutes during 1964. The meetings, which may cover any scientific topic, should last for two weeks or longer and may take the form of practical experimental courses as well as the more usual type with lectures and discussions. Grants may be used to cover, in whole or in part, the travelling and living expenses of visitors, costs of publication, etc. Applications, which must be made before December 15, should be addressed to the Scientific Affairs Division, North Atlantic Treaty Organization, Place du Maréchal de Lattre de Tassigny, Paris 16, from which further information can also be obtained.

\section{University News :}

Aberdeen

N. M. Levy and Dr. M. A. Lappin have been appointed to lectureships in electrical engineering and geology, respectively. Dr. W. L. Cunningham has been appointed to a research fellowship in biological chemistry.

Bristol

DR. P. J. Randle, locturer in biochemistry in the University of Cambridge, has been appointed to the newly established chair of biochemistry, and Mr. J. C. Shepherdson has been appointed to a chair of pure mathematics in respect of his post as reader in mathematics in the University. Both appointments will take effect as from April 1, 1964. The following appointments have also been made: Lectureships, Mr. G. A. Battersby (electrical engineering); Dr. G. I. Fray (organic chemistry); Mr. P. M. Keen (pharmacology); Dr. J. S. Littler (organic chemistry); Dr. T. M. Sutherland (chemical physiology). Research fellowships, Dr. R. R. Hillier (physics); Dr. J. Malos (physics).

East Anglia

MR. M. B. GLAUert, at present senior lecturer in the Department of Applied Mathematics in the University of Manchester, has been appointed professor of mathematics in the School of Mathematical and Physical Sciences. Dr. N. Sheppard, assistant director of research in spectroscopy and lecturer in chemistry in the University of Cambridge, has been appointed professor of chemistry in the School of Chemical Sciences. Dr. I. Gibson has been appointed lecturer in biology in the School of Biological Sciences.
London

Prof. C. A. Frsher, professor of geography in the University of Sheffield, has been appointed to the chair of geography (with reference to Asia), tenable at the School of Oriental and African Studies, from October 1, 1964. The title of professor of industrial and management engineering has been conferred on Prof. S. Eilon, in respect of his post at Imperial College of Science and Technology.

\section{Announcements}

Mr. E. W. MAdGe, of the Dunlop Rubber Co., Ltd., has been awarded the Colwyn Medal for 1963 of the Institution of the Rubber Industry, for his scientific and technological services to the industry. Dr. F. H. Cotton, head of the National College of Rubber Technology, London, has been awarded the Hancock Medal, for his services to the Institution and the rubber industry.

THe Year Book of the Royal Society of Edinburgh, 1963, covering the session 1961-62, includes, besides the obituary notices of Fellows, the proceedings of ordinary meetings, lists of recent awards, the accounts of the Society and the list of Fellows at October 22, 1962 (Pp. 144. Edinburgh: Royal Society of Edinburgh, 1963. 20s.; 3.50 dollars).

Mr. G. L'E. Turner, Museum of the History of Science, Broad Street, Oxford, writes: "I am investigating the development of British microscopes in the nineteenth century. For the investigation of the resolving power of some historical instruments I wish to have the use of a Nobert test plate and a Grayson rulings. I am wondering if there is a reader in possession of one or other of these probe plates who would be prepared to lend it to me for this work. If unable to lend such a plate, I should nevertheless be glad to hear of its whereabouts and any details of its construction and history."

A symposrum on "Productivity in Research", arranged by the Institution of Chemical Engineers, will be held in London during December 11-12. The programme will include sessions on: the poliey of higher industrial management; organization and interaction in research success; the effect of environment. Further information can be obtained from the Institution of Chemical Engineers, 16 Belgrave Square, London, S.W.1.

THE third international congress on catalysis will be held in Amsterdam during July 20-25, 1964. The congress will be devoted to a discussion of the mechanism of heterogeneous catalysis, and papers will be presented on molecular description of the catalytic reaction and its intermediate states and selectivity in heterogeneous catalysis. Further information can be obtained from the secretary of the congress, Dr. D. M. Brouwer, P.O. Box 3003, Amsterdam.

A sYMPOSIUM on "Treatment of Pain in Incurable Disease" will be held at Addenbrooke's Hospital, Cambridge, on January 18. The programme will include: researches on the action of phenol on nerve fibres; films of the treatment of spastic conditions with phenol; recent advances in the treatment of cancer pain; anolgesic and other drugs in the treatment of chronic pain; the surgery of pain. The fee for the symposium will be 1 guinea. Further information can be obtained from the Secretary of the Medical School, Tennis Court Road, Cambridge.

Erratum. In an advertisement (Nature, 199, diii; 1963) of books published by the International Society of Plant Morphologists, Department of Botany, University of Delhi, Delhi 6, one title was erroneously given as Plant Tissue and Organic Culture-A Symposium. For Organic read Organ. 